\title{
Principles in Language Learning Motivation
}

\author{
Oktavian Mantiri \\ Faculty of Education and Psychology, Asia-Pacific International University
}

Copyright (c) 2015 Horizon Research Publishing All rights reserved.

\begin{abstract}
This is a literature review of the teaching principles in English language and their relationships to motivation. This article is based on personal teaching experiences with teacher trainees in the field of language teaching. Motivation is key to successful education; however, it requires the right approaches to benefit teaching and learning. This article explores the importance of meaningful learning and authentic materials in language learning. It also emphasizes the significance of the role of reward in increasing motivation. It argues that rote learning should play minimal role if at all, whereas meaningful learning be the core of the whole experience. Moreover, culture connection, self-confidence, and attitude are considered as other important factors of teaching and learning. In conclusion, this article reiterates the importance of teachers' role in language learning success whereby teachers need to set the stage for learning through creating learning environment that foster meaningful experiential learning and where students could make sense of the whole learning experiences.
\end{abstract}

Keywords Language Learning Motivation, English Learning, Language Teaching Principles, Attitudes in Language Learning

\section{Introduction}

Motivation is key in language learning (Dörnyei, 1998). It is an important element that a learner needs in order for learning to take place. Students usually learn what they need or want to learn, but they have a hard time learning something which they are unmotivated for. The learners usually decide what they would like to learn, but having said that, a teacher can also play a role in influencing the motivation of a student to a certain extent. There have been incidences where a learner might not be interested to learn English at the initial stages, but because of the influence of the teacher the learner became motivated.

In most cases, motivation or lack of it plays a role in the success or failure of the acquisition of second language.

So often, in my experience being a teacher trainer, I would hear teachers say, "My students are not motivated to learn at all, so they don't learn anything." This is typical of novice teachers' assessment towards their teaching experience. However, this is not an isolate case. Experience teachers also face similar situation at times. It is possible that students may come to a language classroom with a very low motivation to learn the language. Teachers may not have much control over the motivation of students, but there is a possibility that teachers could do many things to create or increase students' motivation various ways. Therefore based on this, I would like to explore some practical principles of motivating students to learn English language. The aim of this paper is to discuss how teachers can influence students' motivation in relationship to the various teaching principles, theories, methods and factors relating to it.

\section{Definitions}

Motivation is not a term that could easily be defined in just one or two simple sentences. Most research in language education has defined motivation as an element that is attached to various constructs. Others have listed the characteristics of motivation as a way of defining it. Heckhausen (cited in Dörnyei \& Ottó, [64]) defines motivation as,

A global concept for a variety of processes and effects whose common core is the realization that an organism selects a particular behavior because of expected consequences, and then implements it with some measure of energy, along a particular path.

Bandura (cited in Dörnyei \& Ottó), taking into consideration the various levels of motivation, defined it as, A general construct linked to a system of regulatory mechanisms that are commonly ascribed both directive and activating functions. At the generic level it encompasses the diverse classes of events that move one to action. Attempts to explain the motivational sources of behavior therefore primarily aim at clarifying the determinants and intervening mechanisms that govern the selection, activation, and sustained direction of behavior toward certain goals (p. 64).

Dörnyei and Otto (1998) defines motivation in a general sense as 
The dynamically changing cumulative arousal in a person that initiates, directs, coordinates, amplifies, terminates, and evaluates the cognitive and motor processes whereby initial wishes and desires are selected, prioritized, operationalized, and

(successfully or unsuccessfully) acted out.

The common element found in all of the above definitions is goal and the behavior of a person in a certain way to achieve the goal. Brown (1994, [152]) puts succinctly when he said it, "Motivation is the choices people make as to what experiences or goals they will approach or avoid and the degree of effort they will exert in that respect." It is the inner drive or the inner desire that pushes one to do a particular action. According to Ward (n.d., para. 1), motivation "is a spur to action." It is something that will not let you sit idly. Simply put we can say motivation is a goal-directed behavior. Also according to a behaviorist motivation is the "anticipation of reinforcement" (Brown, 2001, [73]). It is usually defined as a psychological trait, which leads people to achieve some goal.

On a more specific definition of motivation, often studies in second language acquisition draw the distinction line between integrative and instrumental motivation which is used by Robert Gardner and his associates (Gardner, 2012). Meanwhile, Brown (2001, [75]) uses the term orientation instead of motivation. According to him "orientation means a context or purpose for learning; motivation refers to the intensity of one's impetus to learn." Moreover, Gardner and Lambert (cited in Richard-Amato, 1996) explained that when learners wish to integrate and identify themselves with the culture of the second language group, it is said to be integrative orientation, and within this purpose, the level of motivation of the learner may be high or low.

Based on the aforementioned definitions of motivation, it could be said that the students integrative motivation stems from a need to integrate oneself fully into the society, whereas, instrumental motivation refers to motivation to acquire a language to reach the goals of a learner such as graduating, getting a higher pay, translation, etc. Finegan (2004) says that the kind of motivation a learner has affects the mastery of a second language.

In my experience, it is crucial to increase the teachers' awareness of the students learning English purposes. Questions such as 'What drives students to learn English?', 'Are they driven by integrative or instrumental motivation?' among others would set the stage for teachers to prepare the appropriate lessons that would motivate them. Having learned the importance of students' motivation, now let us explore the teaching principles that would contribute to successful learning.

\section{Teaching Principles}

\section{Meaningful Learning and Authentic Materials}

One of the most important things a teacher could do to increase students' motivation is to make learning meaningful. It is generally true in any classes that students would enjoy activities and learn better when learning is made meaningful. The comment I found from my teacher trainees is that 'placing the learners in a real-life learning situation and practicing what to say works better than drilling'. On the contrary, some would say that 'making them memorize a role-play that means nothing to them would only foster rote learning'. An example of a meaningful learning, one of the teacher trainees said that in an English class for nursing students, they may be requested to practice on a role play between the patients and nurses. This kind of activity creates a lot of excitement and would motivate the students to practice and speak English. Brown (2001, [57]) says, "Meaningful learning will lead toward better long-term retention than rote learning."

Moreover, to make learning meaningful, teachers need to consider the activities and the materials used in the classroom. According to Gardner (2006), the materials and activities a teacher uses are important in influencing the student's level of motivation. Furthermore, Fasold and Connor-Linton (2000) says that varied and challenging instructional activities assist students to concentrate and engage in learning and facilitate the second language learning process. As explained earlier, when a student finds the materials a teacher uses are interesting and meaningful, his/her motivation increases. It is this level of motivation that affects the success or failure of language learning. For example, a teacher trainee explained that, in any reading and discussion classes for nursing students, they would be more motivated to participate when the reading passage is authentic and interesting to them.

To sum up the importance of being authentic, Wilga (1989) puts it, students are not robots where they are to be primed or set in motion. Students are not there just to be stuffed with dull, tedious and repetitious materials and rote learning and regurgitate it whenever they are asked. But they are individuals with their own interior motivation determining what they will learn or what they will not.

\section{Anticipation of Reward}

Students' motivation to learn however may also be dependent on their anticipation of reward. According to Skinner (cited in Brown, 2001, [57-58]) one of the most powerful factors in directing one's behavior to the goal that is set by a student could be the anticipation of reward. One suggested idea that was generally agreed upon in my teacher trainee classes, is that to tell the students that they will be given few extra points for speaking English in the class. According to the teacher trainees, this was found to be effective.

Brown (2001) and Snowman (1997) said that students will pursue a goal if they perceived a reward for doing the task. Further, they said that it is important to reinforce the students' behavior by word of encouragements, praise, or a positive comment. Giving extra points for students when they speak 
English tend to make them put more extra effort. Furthermore, as my teacher trainees argued, if the students are given a positive comment or if they get some kind of reward from their activities, it would motivate them to perform better.

In sum, teachers should strive to get learners to see the long term reward of learning English instead of the short term reward. If students can see this, their motivation could be led to intrinsic motivation which according to Brown (2001) is the most powerful rewards within a student.

\section{Intrinsic Motivation and Automaticity}

Brown (1994) defined intrinsic motivation as activities that one does without expecting any apparent reward except for the activity itself. Intrinsic motivation stems from the student's needs, wants, or desires and so external reward is not necessary. Classroom tasks should be designed to meet the intrinsic drives of students as these tasks are self-rewarding and give a greater chance for success. One activity that would be effective is to create an environment where students can practice some authentic role-plays.

Teachers should create an environment for students to communicate without worrying about the forms or structure. The teaching principle of automaticity (University of Alberta, n.d) says that children learn their first language by repetition and practice done in a controlled environment created by teachers. Previously explained examples from teacher trainees would arguably lead to the intrinsic motivation. This however needs to be proven with further studies.

\section{The Language - Culture Connection}

Another important principle is the connection between language and culture. Teachers should constantly seek to increase the motivation of the students. One way to increase students' motivation could be learning the culture of the target language. There have been studies about the relationship between culture and language. Malinowski (1944) stated that an understanding of a language is impossible without continually connecting it to the culture of its operative. In other words, learning a language is inseparable from its culture. Moreover, Byram (1989, [22]) acknowledged that, "as learners learn about language they learn about culture and as they learn to use a new language, they learn to use a new culture". It is therefore crucial to teach language and culture simultaneously in English language teaching. It could be said that without simultaneously teaching language and culture, we are teaching unauthentic symbols which may result in the wrong associations of meaning.

Furthermore, Kitao (cited in Genc \& Bada, 2005) says that experts such as Gardner and Lambert have proved that culture classes can motivate students because learners like culturally based activities, and learning about other people. They also pointed out that the study of culture will increase their curiosity and interest about other people. Since the students are motivated it will then facilitate their language learning and at the same time enable them to take control of their own learning, and this then will lead them to be a self-confident learner.

\section{Self-Confidence}

Self-confidence is an important element both teachers and students needs to possess. The teaching principle of self-confidence is “a person's belief in his or her ability to accomplish the task" (Brown, 2001, [62]). If students believe in themselves, accomplishing a task becomes easier and eventually this will facilitate successful learning and in a way increase their motivation. According to Brown (2001), teachers are to sustain the self-confidence of the students where students already have or build it where it doesn't exist. Teachers also need to build students confidence through reflecting the same elements in their teaching. One of the greatest challenges of teaching for novice teachers is self-confidence. In my experience working with teacher trainees, the constant theme of discussion in the class is on how to build self confidence in teaching. The important principles presented in this article tackle this issue. I would argue that understanding this principles would help build self-confidence for teachers and students alike.

\section{Other Factors for Motivation}

Another area that seems to have a significant effect on motivation is attitude, that is, the attitude towards the target language and people, and attitudes towards the teacher and the classroom environment. According to Gardner and Lambert (1972, cited in Richard-Amato, 1996), 'The learner's ethnocentric tendencies and his attitudes toward the members of the other groups are believed to determine how successful he will be, relatively, in learning the new language'.

One teacher trainee once said, 'I was reading the reflection journal of my students in the Reading and Discussion class and found out that some of my students have a very negative attitude towards reading. As a result, they were not motivated to read the assigned passage that affected their performance in their tests' (personal communication). It is therefore critical for teachers to help students create the right attitude to learn the target language. It may be important for teachers to find out the different kinds of motivation that students come with so they can direct their teaching accordingly.

Teachers should also be mindful that different students respond to different learning strategies. Therefore teachers need to change the strategies of approaching teaching the language according to the needs of students. According to Richard-Amato (1996), increasing students' contact with fluent speakers of the target language, especially peers, can be a great way to increase the motivation of the learner. Inviting fluent speakers of the target language to the classroom, organizing pen-pal or e-pal relationships between 
students and peers who are more advanced in the target language can sometimes provide enough motivation for learners to want to learn the language.

Using computers could be a way to motivate the students. The use of computers gives the students the feeling that they are in control of their own learning. Brown (2001) says that motivation is highest when students are brought into the decision-making process. Roblyer (2005) states that if students see themselves in control of their learning, the result of their learning is intrinsic motivation or a motivation made by the awareness that they are learning. Motivating the students to learn, to enjoy learning and engaging them in learning is important and this can be achieved by the use of computers. The students can do a lot of things using the computers and learn by doing things themselves. In a way they become the creators not just the receivers of knowledge (Lee, 2000). Computers also provide real-life skill-building activities. Therefore, the use of computers in language learning can be a powerful tool not only to motivate the students to learn the language but also in preparing the students for today's technological world.

Lastly, Good and Brophy (cited in Day, 1990, [61]) said that teacher's attempts to arouse students' learning motivation includes "instruction or modeling designed to increase student's metacognitive awareness of their learning efforts in response to the task." The task may include information about mental preparation for learning or structure built into the content, or about how to monitor one's own comprehension and respond to confusion or mistakes. Russell (1996) says that in a learning situation where the learning is authentic and relevant, the learner uses metacognitive understanding to help overcome some of the frustrations of learning and bring such understanding to the task.

\section{Conclusion}

In order to have a successful teaching and learning English, teachers need to figure out the types of motivation the students have. Once the students' motivation is identified, teachers need to create learning English that is meaningful and relevant to them. Motivation springs from within; it can be sparked, but it cannot be imposed from without. As teachers we need to realize that rewards play important part in the initial stage of building motivation. Praise, positive word of encouragements, and giving extra point grades do help in motivation building. It is not only the teacher's or parent's job to motivate the students; they need to assume responsibility for their own learning. There is a need to constantly help students to look deep inside them in order to find they want to learn which will then lead to motivation. Also, we need to realize that motivation is not a fixed state but rather a dynamically evolving and changing entity linked with the ongoing process of learning in an authentic context. Confidence building is crucially important for students. This needs to be done by teachers through their teaching because this will lead to the last but not the least important principles, i.e. attitude.

In conclusion Brown (2001, [81]) emphasized that teachers should not think of themselves as someone who constantly had to deliver information to students, but rather to be more like a facilitator of learning whereby setting the stage for learning to take place and motivate the students to use their thinking abilities and to help them to channel their abilities into something productive.

\section{REFERENCES}

[1] Brown, H., D. (1994). Principles of language learning and teaching (3rd ed.). New Jersey: Prentice Hall Regents, Englewood Cliffs.

[2] Brown, H., D. (2001). Teaching by principles: An interactive approach to language pedagogy (2nd ed.). White Plains, New York: Longman.

[3] Byram, M. (1989). Cultural Studies in Foreign Language Education. Clevedon, Avon: Multilingual Matters

[4] Day, R. R. (1990). Teacher observation in second language teacher education. In J. C., Richards \& D., Nunan (Eds.), Second language teacher education (pp 43-61). Cambridge: Cambridge University Press.

[5] Dornyei, Z., \& Otto, I. (1998). Motivation in action: A process model of L2 motivation. Working Papers in Applied Linguistics. Vol. 4, pp. 43-69. Thames Valley University, London. Retrieved October 20, 2014, from http://88.198.249.35/d/eprints-nottingham-ac-uk-39-0-Motiv ation_in_action-pdf.pdf

[6] Dörnyei, Z., (1998). Motivation in second and foreign language learning. Language Teaching, 31, pp. 117-135. doi:10.1017/S026144480001315X

[7] Fasold, R., \& Connor-Linton, J. (2004). An introduction to language and linguistics. Cambridge: Cambridge University Press.

[8] Finegan, E. (2004). Language its structure and use (4th ed.). USA: Wadsworth.

[9] Gardner, R.C. (2006, December). Motivation and second language acquisition. University of Western Ontario. Retrieved October 20, 2014 from http://publish.uwo.ca/ gardner/SPAINTALK.pdf.

[10] Gardner, R.C. (2012). Integrative motivation and global language (English) acquisition in Poland. Studies in Second Language Learning and Teaching. Vol. 2(2). Pp. 215-226. Retrieved from https://repozytorium.amu.edu.pl/jspui/bitstre $\mathrm{am} / 10593 / 3265 / 1 / \mathrm{SSLLT} \% 202 \% 282 \% 29 \% 20215-226 \% 20 \mathrm{G}$ ardner.pdf

[11] Genc, B. \& Bada, E. (2005, April). Culture in language learning and teaching. The Reading Matrix, 5(1). Retrieved October 20, 2014, from

http://www.readingmatrix.com/articles/genc_bada/article.pdf

[12] Lee, K-W. (2000). English teachers' barriers to the use of computer-assisted language learning. The Internet TESL 
Journal (VI) 12. Retrieved November 5, 2014, from http://iteslj.org/Articles/Lee-CALLbarriers.html

[13] Malinowski, B. (1944). A Scientific Theory of Culture and Others Essays. Chapel Hill, N. Carolina: The University of North Carolina Press.

[14] Richard-Amato, P. A (1996). Making it happen: Interaction in the second language classroom from theory to practice (2nd ed.) New York: Longman

[15] Roblyer, M. D. (2005). Integrating educational technology into teaching (3rd ed.). New York: Pearson Prentice Hall.

[16] Russell, A. L. (1996). Six stages for learning to use technology. In J. J., Hirschbuhl \& D., Bishop (eds.), Computers in Education (8th ed.), (pp 102-107). Dushkin: McGraw Hill.

[17] Snowman, B. (1997). Psychology applied to teaching. Project-based learning space. Houghton Mifflin. Retrieved
October 27, 2014 from http://college.hmco.com/education/p bl/tc/motivate.html.

[18] University of Alberta. (n.d). Automaticity in Language Teaching and Learning. Retrieved November 20, 2014 from http://www.educ.ualberta.ca/staff/olenka.bilash/best $\% 20$ of $\%$ 20bilash/automaticity.html

[19] Ward, S. (n.d.). Motivation. October 19, 2014 from http://sbinfocanada.about.com/od/motivation/g/motivation.ht $\mathrm{m}$.

[20] Wilga, M. R. (1989). Interaction and communication in the class in an age of technology. Harvard University. Retrieved November 20, 2014 from http://books.google.com/books?hl=en \&lr=\&id=3duWbNx-P gwC\&oi $=$ fnd \&pg $=$ PA186\&dq $=$ Motivation + springs + from + w ithin $\% 3 \mathrm{~B}+\mathrm{it}+$ can + be + sparked, + but + it + cannot + be + imposed + from + without. + \&ots $=$ Fv2ybzGqFT\&sig=bNyJzhiD7ZOUc iUnYvtSoRiPOCM\#PPA186,M1. 